\title{
PRZEJAWY NIEDOSTOSOWANIA SPOŁECZNEGO U PODOPIECZNYCH CAŁODOBOWYCH PLACÓWEK OPIEKUŃCZO-WYCHOWAWCZYCH
}

\begin{abstract}
Abstrakt: Podjęta w tekście problematyka dotyczy funkcjonowania dziecka w sytuacji nieprawidłowych relacji z rodzicami. Uwzględniono analizę więzi i przywiązania, które wywierają istotny wpływ na kształt współczesnej praktyki społecznej w zakresie wychowania, terapii dzieci i opieki nad nimi. Skoncentrowano się na poszukiwaniu przyczyn zakłócających prawidłową więź dziecka z rodzicami, którzy nie są w stanie sprawować funkcji opiekuńczo-wychowawczej. Badaniami objęto dzieci, które na podstawie orzeczenia sądu korzystają z pieczy zastępczej. Celem była próba rozpoznania zachowań problemowych podopiecznych „Domów dla Dzieci" w momencie ich przybycia do placówki. Zebrany i opisany materiał empiryczny będzie inspirował wychowawców do pogłębionej analizy problemów osobistych wychowanków i poszukiwania strategii radzenia sobie z trudnościami wychowawczymi oraz budowania bezpiecznej więzi między dzieckiem a opiekunem.
\end{abstract}

Słowa kluczowe: opieka zastępcza, rodzina dysfunkcjonalna

\section{ZARYS TEORETYCZNY PODJĘTYCH BADAŃ}

W tekście zwracamy uwagę na pojawiające się implikacje w funkcjonowaniu dziecka w sytuacji zaistnienia dysfunkcji w obszarze relacji między dzieckiem a jego rodzicami. W różnych kontekstach teoretycznych możemy spotkać się z nieco innymi definicjami pojęcia relacji. Pojawiają się m.in. takie określenia, jak „przywiązanie” czy „więź”. Pojęcie „przywiązania” i jego znaczenie dla zachowań niedostosowanych podkreślane było w różnych teoriach psychologicznych, socjologicznych i pedagogicznych. W kryminologii większość prac omawiających przestępczość 
nieletnich uwzględnia teorię Travisa Hirschiego, która zwraca uwagę na cztery komponenty więzi jednostki ze społeczeństwem: przywiązanie, zaangażowanie, zaabsorbowanie oraz przekonanie o konieczności przestrzegania norm społecznych (Siemaszko 1993). Pozostają one ze sobą w ścisłym związku, lecz mogą także wywierać niezależny wpływ na dewiacyjne zachowanie (Siemaszko 1993). Hirschi przywiązaniu nadaje szczególne znaczenie i traktuje je jako wyjątkowy element systemu więzi jednostki ze społeczeństwem. Polega ono na tworzeniu emocjonalnych związków człowieka $\mathrm{z}$ innymi. Jeśli młoda osoba przywiązana jest do swojego otoczenia, odnosi się do niego z szacunkiem, zależy jej na nim. Wówczas uwzględniać będzie opinie i potrzeby innych ludzi, gdyż jest moralnie zobligowana do przestrzegania norm wyznawanych w jej środowisku.

Taki sposób rozumienia przywiązania zbliżony jest do pojęć wywodzących się z innych teorii, jak „super ego” czy też „internalizacja”. W zależności od przyjętego paradygmatu teoretycznego przywiązanie może być różnie pojmowane. Na przykładzie teorii Hirschiego wskazaliśmy na sposób rozumowania tego pojęcia w kryminologii. Jednak ze względu na to, że niniejszy artykuł odnosi się do oddziaływań wychowawczych podejmowanych w całodobowych placówkach, wyjątkowo cenne będzie omówienie resocjalizacyjnych implikacji wynikających z teorii przywiązania Bowlby’ego, według której (w odróżnieniu od socjologicznych koncepcji) przywiązanie uznaje się za relację odgrywającą szczególną rolę w kształtowaniu się osobowości człowieka.

John Bowlby uznawany jest w psychologii za twórcę teorii przywiązania. Punktem odniesienia do jego rozważań teoretycznych była psychoanaliza. Koncepcja przywiązania jest efektem inspiracji badacza pracami psychoanalitycznymi i wywodzi się z teorii relacji z obiektem, stąd też wiele zawdzięcza Melanii Klein. Teoria przywiązania nie wchodzi w strukturę psychoanalizy ani teorii relacji z obiektem, ma jednak z nimi wiele wspólnego. Prace Bowlby'ego oraz badania Mary Ainsworth stanowią podstawę współczesnej teorii przywiązania. Dla rozważań brytyjskiego psychiatry istotne znaczenie miała etologia, czyli nauka zajmująca się badaniem zwierząt $w$ ich naturalnym środowisku oraz poznawaniem ogólnych praw rządzących funkcjonowaniem wszystkich systemów biologicznych (Pervin, John 2002). Praktyka kliniczna i analiza literatury przyczyniły się do sformułowania przez Bowlby’ego teorii behawioralnego systemu przywiązania, według której każdego człowieka cechuje posiadanie uwarunkowanego biologicznie systemu przywiązania. Miłość dzieci do matek i miłość matek do dzieci uznaje za oczywistą właściwość natury ludzkiej. Przywiązanie dziecko-matka umożliwia bezpieczną eksplorację świata i rozstanie z opiekunem. Jeśli w obrębie tej relacji dochodzi do odchyleń od normy, wówczas w perspektywie koncepcji Bowlby'ego istnieje tendencja do oceny tego stanu jako patologicznego. Teoria przywiązania opiera się na założeniu, że 
dzieci, których rodzice potrafią wyczuwać ich potrzeby emocjonalne i odpowiednio na nie reagować, mają większe szanse wytworzenia stabilnego modelu wzajemnej interakcji, co prowadzi do równowagi emocjonalnej. I odwrotnie - rodzice nieokazujący tolerancji wobec ekspresji emocjonalnej dzieci lub niezdolni do skutecznej reakcji na ich cierpienie często pozbawiają potomstwo zdrowej relacji. Badania pokazują, że niewłaściwa relacja między rodzicem a dzieckiem wiąże się z takimi cechami u dzieci, jak: agresywne zachowanie, braki w zakresie kompetencji społecznych, niskie poczucie własnej wartości i utrudnione kontakty z rówieśnikami. Ponadto brak bezpiecznej więzi łączy się zarówno z większym poziomem stresu matki, jak i z zaniedbywaniem i wykorzystywaniem dziecka.

Bowlby przez wiele lat pracował $\mathrm{z}$ dziećmi niedostosowanymi społecznie, dlatego też w swoich założeniach teoretycznych za punkt wyjścia przyjął dane pochodzące z obserwacji dzieci uwikłanych w sytuacje patogenne. Na bazie uzyskanych danych dążył do wyjaśnienia etiologii symptomów psychopatologicznych. Jego zdaniem poznanie funkcjonowania człowieka wymaga obserwacji wyprzedzającej pojawienie się symptomów, a nie, jak to jest w psychoanalizie, retrospekcji doświadczeń (Bowlby 2007). Celem jego badań było opisanie bezpiecznych i dysfunkcyjnych wzorców reakcji pojawiających się regularnie we wczesnym dzieciństwie i mających poważne konsekwencje w późniejszym życiu.

Koncepcja przywiązania wywarła istotny wpływ na kształt współczesnej praktyki społecznej w zakresie wychowania i terapii dzieci oraz opieki nad nimi. Szczególnym uznaniem cieszy się założenie mówiące o stałości i wrażliwej reaktywności opiekuna - fundamentalnych elementach zapewniających dziecku poczucie bezpieczeństwa.

Istnieje wiele przyczyn zakłócających prawidłową więź dziecka z rodzicem. Można je podzielić na trzy kategorie:

1) Udział rodziców lub innych znaczących opiekunów, tj. wykorzystywanie, zaniedbywanie, depresja rodziców czy zaburzenia psychiczne;

2) Udział dziecka, tj. trudny temperament, niedojrzałość, alkoholowy zespół płodowy;

3) Udział środowiska, tj. ubóstwo, zamieszkiwanie poza domem rodzinnym, przemoc w domu czy w środowisku.

Powyższe przyczyny mogą kształtować nieprawidłowy wzorzec przywiązania, co z kolei wpływa na wiele innych aspektów funkcjonowania dziecka. Objawy wynikające $\mathrm{z}$ posiadania niewłaściwego wzorca mogą być prawie niewidoczne lub wyraźnie dostrzegalne. Można podzielić je na sześć kategorii:

1) Zachowanie: zachowania opozycyjne, dewiacyjne, impulsywne, destrukcyjne, agresywne, nastawione na wykorzystywanie innych, nadpobudliwe, autoagresywne, okrutne wobec zwierząt; 
2) Emocje: silna złość, depresja, poczucie beznadziejności, zmienność nastrojów, wysoki poziom lęku i niepokoju (często ukrywany), częste irytowanie się, nieadekwatne reakcje emocjonalne;

3) Myśli: negatywne przekonania dotyczące siebie, relacji z innymi oraz życia, trudności z utrzymaniem uwagi oraz problemy z uczeniem się;

4) Relacje $z$ innymi: brak zaufania, manipulowanie, nieprzekazywanie ani nieodbieranie prawdziwych emocji, niestabilne relacje rówieśnicze, obwinianie innych za swoje błędy lub problemy, krzywdzenie innych;

5) Fizyczne: niedbanie o własną higienę, samookaleczanie, moczenie nocne, wysoka tolerancja na ból, genetyczne predyspozycje do depresji i nadpobudliwości;

6) Moralne: brak empatii, współczucia i wyrzutów sumienia, deficyt prospołecznych wartości, identyfikowanie się ze złem i negatywnymi aspektami funkcjonowania człowieka.

Powiązanie wewnętrznej podatności (np. emocjonalnych czy poznawczych deficytów) i negatywnych czynników środowiskowych (np. wykorzystywanie i zaniedbywanie dziecka) tworzy kontekst, który może prowadzić do zachowań bazujących na przemocy. Ekstremalnie agresywni sprawcy przemocy doświadczyli maltretowania, charakteryzowali się zaburzeniami poznawczymi, kłopotami z koncentracją oraz impulsywnością (Lewis 1990). Dlatego koncentrując się na zależności między niewłaściwym przywiązaniem i agresją, należy zwrócić uwagę także na to, że udział emocjonalnych, poznawczych, społecznych i biologicznych czynników (Levine 1996) ma również istotny wpływ na pojawienie się zachowań agresywnych i niepożądanych (National Research Council 1993).

W sytuacji, gdy rodzice dziecka nie są w stanie sprawować funkcji opiekuńczo-wychowawczej, na podstawie orzeczenia sądu dzieci korzystają z pieczy zastępczej. Ma ona na celu przygotowanie dziecka i rodziców do odbudowania prawidłowej relacji. Natomiast gdy jest to niemożliwe - dążenie do przysposobienia podopiecznego lub opiekę i wychowanie w środowisku zastępczym (Ustawa $z$ dnia 9 czerwca 2011 r. o wspieraniu rodziny i systemie pieczy zastępczej, art. 33). Piecza zastępcza może być realizowana $\mathrm{w}$ formie rodzinnej lub instytucjonalnej. „Domy dla Dzieci” są specyficzną formą realizacji pieczy instytucjonalnej, która dąży do osiągnięcia rodzinnej atmosfery. Są to całodobowe placówki opiekuńczo-wychowawcze typu socjalizacyjnego, gdzie może przebywać maksymalnie czternastu podopiecznych pod nadzorem wychowawców. Zazwyczaj w tego rodzaju placówkach są umieszczane dzieci między 10. a 18. rokiem życia wymagające szczególnej opieki lub mające trudności w przystosowaniu się do życia w rodzinie (Ustawa z dnia 9 czerwca 2011 r. o wspieraniu rodziny i systemie pieczy zastępczej, art. 95). Wychowawcy bazują na indywidualnym planie pracy z dzieckiem, analizie potrzeb, zasobów oraz sytuacji i środowiska rodzinnego. 


\section{CEL I METODOLOGIA PODJĘTYCH BADAŃ}

Teoria przywiązania Bowlby’ego, będąca podstawą metodologiczną dla podjętych badań, nawiązuje do istotnych aspektów niedostosowania społecznego. Stanowi punkt wyjścia dla różnych typów interwencji psychopedagogicznych.

Celem podjętych analiz było zdiagnozowanie zachowań problemowych wychowanków „Domów dla Dzieci” w momencie ich przybycia do placówki. W badaniach wzięło udział 35 podopiecznych z 3 „Domów dla Dzieci”: 7 dzieci nie brało udziału w badaniach ze względu na zbyt krótki okres pobytu lub wiek (kwestionariusz przewidywał badanie dzieci między 13. a 18. rokiem życia). Inspiracją dla badań było tworzenie „Domów dla Dzieci”. Tak więc zachowanie podopiecznych było monitorowane od początku umieszczenia ich w instytucjonalnej pieczy zastępczej.

Zgodnie z założonymi celami sformułowano następujące pytania badawcze:

1) Jakie zachowania problemowe przejawiają dzieci umieszczane w całodobowej placówce opiekuńczo-wychowawczej?

2) Jaki poziom zachowań problemowych przejawiają podopieczni, którzy zostali przeniesieni do młodzieżowych ośrodków wychowawczych?

Zachowania problemowe zdiagnozowane zostały przy pomocy kwestionariusza Achenbacha. Poza poszczególnymi zachowaniami problemowymi, w zależności od tego, jakie objawy dominują w obrazie klinicznym dziecka, możemy dostrzec internalizacyjny lub eksternalizacyjny profil niedostosowania społecznego (Kazdin, Weisz 2006). Wśród objawów występujących w profilu internalizacyjnym znajdują się te, które są skierowane do wewnątrz i wiążą się z nadmierną kontrolą zachowania (Wolańczyk 2002), czyli wycofywanie się z sytuacji społecznych, izolacja, objawy somatyczne, lęk czy depresja. Do objawów eksternalizacyjnych należą te, które są skierowane na zewnątrz (Achenbach, Edelbrock 1978, s. 125-130), czyli zachowania określane mianem niedostosowanych i agresywnych, występujące w różnych sytuacjach i będące źródłem problemów dla innych osób. Cechują się one niedostateczną kontrolą i w związku ze swoją uciążliwością doprowadzają do konfliktów między wychowankiem a otoczeniem społecznym (Wolańczyk 2002). Nie oznacza to, że podopieczny przejawiający zaburzenia eksternalizacyjne nie odczuwa żadnych dolegliwości wynikających ze swojego niedostosowania. Doświadcza on w pewnym stopniu wewnętrznego dyskomfortu, lecz siła tych objawów jest stosunkowo mała w porównaniu z odczuwaniem problemów wynikających z ukierunkowania energii na zewnątrz. 


\section{PREZENTACJA UZYSKANYCH WYNIKÓW}

Z poniższej tabeli wynika, że prawie połowa dzieci (49\%) umieszczanych w „Domach dla Dzieci” uzyskuje w kwestionariuszu zachowań problemowych wynik całkowity w przedziale klinicznym. Wśród 51\% badanych uzyskujących wynik ogólny w przedziale normy znajdują się osoby, które w szczegółowych podskalach zachowań problemowych uzyskały wynik w obszarze klinicznym. Oznacza to, że do placówki socjalizacyjnej często trafiają dzieci wymagające specjalistycznej pomocy pedagogiczno-psychologicznej. Zgodnie z założeniami „Dom dla Dzieci” ma pełnić funkcje opiekuńcze i wychowawcze, natomiast przyglądając się badanym podopiecznym, można dostrzec, że istnieje konieczność podejmowania wobec nich specjalistycznych interwencji uwzględniających indywidualne potrzeby poszczególnych dzieci. Ze względu na różnorodne tło przejawianych zaburzeń dzieci wymagają przede wszystkim oddziaływań terapeutycznych, medycznych i reedukacyjnych. Fakt, że prawie połowa podopiecznych przejawia liczne zachowania problemowe sugeruje, że albo decyzja o umieszczeniu dziecka $\mathrm{w}$ instytucjonalnej pieczy zastępczej jest podejmowana bardzo późno przez stosowne władze, albo od momentu orzeczenia o umieszczeniu dziecka w „Domu dla Dzieci” do czasu jego faktycznego znalezienia się w tej instytucji doszło do nasilenia się objawów.

Troje z badanych podopiecznych mimo wielu wysiłków personelu pedagogicznego zostało przeniesionych do młodzieżowego ośrodka wychowawczego. Osoby te $\mathrm{w}$ kwestionariuszu zachowań problemowych uzyskiwały wynik całkowity w przedziale klinicznym lub granicznym. Spośród wszystkich skal problemowych najwyższe wyniki uzyskane zostały w zakresie zachowań niedostosowanych i agresywnych. Oznacza to, że dzieci przejawiały zachowania antagonistyczno-destrukcyjne oraz opozycyjno-buntownicze. Wykazywały się nieposłuszeństwem w placówce i w szkole, mówiły poza kolejnością, często się spierały, były impertynenckie wobec personelu, okrutne, znęcały się nad innymi. Wymagały poświęcania im uwagi, zaś swoim zachowaniem dezorganizowały dyscyplinę w grupie i przeszkadzały innym kolegom. Niszczyły własne i cudze rzeczy, przechwalały się, często bywały zazdrosne, krzykliwe, wybuchowe i nieprzewidywalne. Popisywały się i brały udział w bójkach. Wobec innych formułowały liczne oczekiwania i chciały, aby ich żądania były natychmiast spełniane, przy czym łatwo doznawały rozczarowania. Mówiły zbyt dużo, były uparte, ponure, drażliwe i skore do gniewu. Groziły innym, atakowały fizycznie. 
Tabela 1. Podopieczni uzyskujący wyniki w normie i obszarze klinicznym w wyniku całkowitym i typie niedostosowania społecznego

\begin{tabular}{|l|c|c|c|c|}
\hline \multicolumn{1}{|c|}{ Profil } & Norma & $\%$ & Przedział kliniczny & $\%$ \\
\hline Wynik całkowity & 18 & 51 & 17 & 49 \\
\hline Eksternalizacyjny & 12 & 34 & 23 & 66 \\
\hline Internalizacyjny & 16 & 46 & 19 & 54 \\
\hline
\end{tabular}

Źródło: badania własne

Zgodnie z założeniami kwestionariusza Achenbacha poszczególne zachowania problemowe mogą stworzyć dwa profile, tj. profil o typie internalizacyjnym i profil o typie eksternalizacyjnym. Wśród podopiecznych przyjmowanych do placówki dominuje eksternalizacyjny profil zachowań problemowych. Tak więc u większości badanych obserwujemy więcej zachowań problemowych o charakterze eksternalizacyjnym w stosunku do zachowań internalizacyjnych. Oznacza to, że osoby $\mathrm{z}$ otoczenia $\mathrm{w}$ większym stopniu doświadczają cierpienia w związku z problemowym zachowaniem się badanych osób niż sami badani.

W sumie liczba poszczególnych zaburzeń behawioralnych u badanych osób wynosi 58. Oczywiście u jednego dziecka mogą współwystępować pewne zachowania problemowe. Natomiast biorąc pod uwagę, że grupa badanych składała się z 35 dzieci, można stwierdzić, iż mamy do czynienia z grupą, wśród której część podopiecznych istotnie pozostaje poza normą kliniczną na kilku wymiarach zachowań problemowych. W momencie trafienia do „Domu dla Dzieci” największa liczba podopiecznych przejawiała zaburzenia myślenia - 54\% (19 osób). Oznacza to, że wykazują oni zachowania, które mogą być traktowane jako objawy zaburzeń psychicznych, takich jak: psychoza, zaburzenie obsesyjno-kompulsyjne i lękowe. Posiadają skłonności do umyślnego okaleczania się, zachowań samobójczych, wielokrotnie powtarzają pewne czynności, nieadekwatnie się zachowują oraz mają nietypowe pomysły i myśli.

Na drugim miejscu znalazły się zaburzenia somatyczne - 31\% . Ta część badanych zgłasza dolegliwości w postaci zawrotów głowy, zmęczenia, których przyczyny nie są rozpoznawane przez lekarzy.

Na trzeciej pozycji znalazły się zachowania niedostosowane występujące u $26 \%$ badanych. Podopieczni ci kłamią i oszukują i wydaje się, że nie odczuwają winy $\mathrm{z}$ powodu niewłaściwego zachowania. Wchodzą $\mathrm{w}$ relacje $\mathrm{z}$ osobami, które łatwo wpadają w kłopoty, wolą przebywać ze starszymi od siebie kolegami, wchodzą w konflikty z prawem, spożywają alkohol i przeklinają. Mają także problemy z poprawnym zachowaniem w szkole, wagarują i spóźniają się na lekcje.

Kolejne zaburzenia (u 20\% podopiecznych) przejawiają przez wycofanie oraz lęk i depresję. Dzieci wolą raczej być same niż z innymi, często się dąsają, są skryte 
i odmawiają rozmowy. Mogą być nieśmiałe i bojaźliwe. Są mało aktywne, powolne lub brakuje im energii. Wycofują się i nie angażują w działania innych. Wyraźnie częściej od swoich rówieśników patrzą bez wyrazu ze wzrokiem skierowanym przed siebie.

Podopieczni z podwyższonym poziomem lęku i depresji zaliczani są do grupy bardziej bojaźliwych. Częściej płaczą i skarżą się na samotność. Uważają, że inni chcą im coś zrobić. Czują się urażeni, gdy ktoś ich krytykuje, skarżą się, że nikt ich nie kocha, czują się bezwartościowi lub gorsi od innych, są nerwowi, przewrażliwieni, spięci oraz przesadnie stosują się do zasad. Bywa i tak, że nadmiernie starają się zadowolić innych. Bywają podejrzliwi, obawiają się popełnienia błędów i w związku z tym przesadnie się martwią. Można łatwo wprawić ich w zakłopotanie i wzbudzić w nich poczucie winy. Cechują się wysoką wrażliwością na odrzucenie, unikają kontaktów $\mathrm{z}$ innymi i wycofują się z nich, nie wierząc $\mathrm{w}$ to, że będą akceptowani. Zwykle stwierdza się u nich niskie poczucie własnej wartości, tendencję do niedoceniania swoich osiągnięć, niechęć do podejmowania osobistego ryzyka z obawy przed niepowodzeniem. Ostatecznie ten odsetek badanych można określić mianem nieszczęśliwych, smutnych i przygnębionych.

Zaledwie u $17 \%$ badanych pojawiły się problemy społeczne. Wyniki takie pozwalają przypuszczać, że w związku z brakiem odpowiedniej opieki ze strony dorosłych 83\% dzieci zostało zmuszonych do samodzielnego radzenia sobie w życiu. Większość z nich rzadko płacze i nie skarży się, że są niekochane, choć tak pewnie czują. Mają dobre kontakty z rówieśnikami. Nie zgłaszają wychowawcom, że ktoś chce im coś zrobić. Nie sprawiają wrażenia, że czują się gorsi i mniej wartościowi od innych. Nie są wyśmiewani przez swoich kolegów z klasy.

U $14 \%$ podopiecznych pojawily się zachowania problemowe w postaci agresji sprawiające duży problem w społeczności całej placówki. Zazwyczaj wymagają one długotrwałych oddziaływań psychokorekcyjnych. Najczęściej przejawiają się w zachowaniach opozycyjno-buntowniczych wobec wychowawców oraz przemocą wobec innych dzieci. W związku z tym wychowawcy muszą zwracać szczególną uwagę na zapewnienie bezpieczeństwa pozostałym podopiecznym. Wydaje się, iż procent ten w stosunku do pozostałej liczby zaburzeń jest niewielki, jednak należy pamiętać, że jedna osoba agresywna krzywdzi wiele innych osób wokół siebie. Tak więc zachowania tego rodzaju stanowią duże utrudnienie w pracy wychowawców placówek, które nie mają charakteru resocjalizacyjnego.

U $11 \%$ podopiecznych występują zaburzenia uwagi. Nie potrafią się skoncentrować i mają trudności ze skupieniem się przez dłuższy czas, nie wywiązują się ze zleconych zadań, nie kończą rozpoczętych wcześniej czynności, nie potrafią usiedzieć w miejscu, są niespokojni, zbyt ruchliwi, nieuważni i łatwo się rozpraszają. Mają trudności z wykonywaniem poleceń, pracują poniżej swoich możliwości, nie 
wykorzystując swojego potencjału, przez co nie osiągają tyle, ile by mogli. Zadania wykonują niedokładnie i pobieżnie. Niektórzy z nich mogą zbyt często pogrążać się w marzeniach i własnych myślach. Są impulsywni i działają bez zastanowienia, bywają także nerwowi, przewrażliwieni i spięci. Mają trudności w nauce i niską motywację do podejmowania zadań szkolnych. Cechują się apatią, mogą sprawiać wrażenie młodszych, niż są w rzeczywistości.

Tabela 2. Liczba osób pozostających w przedziale normy i przedziale klinicznym w obszarze poszczególnych wymiarów zachowań problemowych

\begin{tabular}{|l|c|c|c|c|}
\hline \multicolumn{1}{|c|}{ Zmienna } & $\begin{array}{c}\text { Liczba osób } \\
\text { w przedziale normy }\end{array}$ & $\%$ & $\begin{array}{c}\text { Liczba osób } \\
\text { w przedziale klinicznym }\end{array}$ & $\%$ \\
\hline Wycofanie & 28 & 80 & 7 & 20 \\
\hline Zaburzenia somatyczne & 24 & 69 & 11 & 31 \\
\hline Lęk i depresja & 28 & 80 & 7 & 20 \\
\hline Problemy społeczne & 29 & 83 & 6 & 17 \\
\hline Zaburzenia myślenia & 16 & 46 & 4 & 54 \\
\hline Zaburzenia uwagi & 31 & 89 & 5 & 11 \\
\hline Zachowania agresywne & 30 & 74 & 9 & 14 \\
\hline Zachowania niedostosowane & 26 & & 58 & 26 \\
\hline Razem & & & & \\
\hline
\end{tabular}

Źródło: badania własne

\section{PODSUMOWANIE}

Wiele dzieci w momencie umieszczenia w całodobowej placówce opiekuńczo-wychowawczej nie potrafi współdziałać z innymi osobami, ma szereg objawów, które stanowią wyzwanie dla pedagogów. Biorąc pod uwagę uzyskane wyniki i przyjęte założenia teoretyczne, można sformułować pewne postulaty dotyczące pracy w całodobowych placówkach opiekuńczo-wychowawczych.

Początkowym wyzwaniem dla wychowawcy jest stworzenie takiej relacji, w której młoda osoba będzie stopniowo odbudowywać zaufanie, będzie uczyła się kooperacji, empatii i wykształci w sobie poczucie pewności niezbędne do prawidłowego funkcjonowania w „Domu dla Dzieci” i społeczeństwie.

$\mathrm{Z}$ tego powodu podstawowym celem pracy podejmowanej przez wychowawców jest inicjowanie bezpiecznego przywiązania między dzieckiem a opiekunem. Aby osiągnąć ten cel, konieczne jest odtworzenie pewnych elementów tej relacji, które były niedostępne we wczesnym dzieciństwie. W związku z tym dzieci muszą doświadczyć empatii, mieć poczucie zsynchronizowanej interakcji polegającej na wzajemnym dopasowywaniu się z wychowawcą oraz możliwość uzyskiwania 
pozytywnych efektów i wsparcia. Czyli przy pomocy „społecznych wyzwalaczy” należy aktywować te struktury mózgowe, które odpowiedzialne są za prawidłowe przywiązanie.

Dodatkowo, aby oddziaływania były skuteczne, wymagają one uwzględnienia całego systemu, w którym osadzony jest podopieczny, czyli interwencje powinny dotyczyć także obojga rodziców, całej rodziny, a nawet społeczności, w której znajduje się dziecko. Osoby niedostosowane społecznie często przeciwstawiają sobie rodziców i innych dorosłych. Stąd też efektywne oddziaływania muszą uwzględnić społeczny system podopiecznego oraz całej rodziny.

Interwencje psychokorekcyjne powinny się koncentrować na świadomości, ciele, zachowaniu, emocjach, relacji, wartościach. Podejmowane oddziaływania powinny być zróżnicowane: eksperymentalne, psychoedukacyjne, poznawcze, skupione na umiejętnościach podopiecznego. Takie podejście wynika z uznania, że wiele czynników wchodzi ze sobą w interakcję i w efekcie dochodzi do zaburzeń lub poprawy funkcjonowania.

Wprowadzanie zmian powinno dotyczyć wielu obszarów funkcjonowania dziecka. Warto zainteresować się problemami osobistymi wychowanka, systemem przekonań, wzorcami relacji interpersonalnych, strategiami radzenia sobie, sposobami nagradzania siebie, tworzeniem planów itp.

\section{LITERATURA}

Achenbach M.T., Edelbrock C., 1978, The classification of child psychopathology: A Review and Analysis of Empirical Efforts. "Psychological Bulletin", nr 85, 1275-130.

Bowlby J., 2007, Przywiazanie. Warszawa, PWN.

Kazdin E.A., Weisz J.R., 2006, Psychoterapia dzieci i młodzieży. Metody oparte na dowodach. Kraków, Wydawnictwo Uniwersytetu Jagiellońskiego.

Levine I., 1996, Preventing violence among youth. "American Journal of Orthopsychiatry", no 66, 320-322.

Lewis D., 1990, Neuropsychiatric and experiential correlates of violent juvenile delinquency. "Neuropsychology Review", vol. 1.

National Research Council, 1993, Understanding and preventing violence. Washington, DC., National Academy Press.

Pervin L.A., John O.P.,2002, Osobowość. Teoria i badania. Kraków, Wydawnictwo Uniwersytetu Jagiellońskiego.

Siemaszko A., 1993, Granice tolerancji. Warszawa, PWN. 
Ustawa o wspieraniu rodziny i systemie pieczy zastępczej $z$ dnia 9 czerwca $2011 \mathrm{r}$. (Dz. U. 2015, poz. 332).

Wolańczyk T., 2002, Zaburzenia emocjonalne i behawioralne u dzieci i młodzieży szkolnej w Polsce. Warszawa, Akademia Medyczna.

\title{
MANIFESTATIONS OF SOCIAL MALADJUSTMENT IN CHILDREN IN CARE IN CIRCADIAN EDUCATIONAL CARE FACILITIES
}

\begin{abstract}
The article discusses the problems concerning the child's functioning in the situation of a dysfunction in the sphere of relationships with parents. In the sphere of existing relationships the analysis of ties and attachment, which have influenced the shape of contemporary social practice in the area of care, education, and children's therapy, has been taken into account. The author focuses on seeking the causes which hamper the normal bond of the child with his/ her parents who are unable to exercise the educational-care function. The studies cover children who, by the ruling of the court, are under the foster care system. The aim of the studies was to identify the problem behaviors of children in care of "Children's Home" (orphanage-type center) at the moment of their arrival at the facility. The collected and described empirical material will inspire counselors/supervisors to analyze in depth the personal problems of children in their care and to seek the strategy for dealing with educational difficulties, and build a safe bond between the child and the counselor.
\end{abstract}

Keywords: foster care, dysfunctional family 